\title{
Dry Ports in European and North American Intermodal Rail Systems: two of a kind?
}

\author{
JEAN-PAUL RODRIGUE \\ Department of Global Studies \& Geography, \\ Hofstra University, Hempstead, New York 11549, USA \\ E-mail: jean-paul.rodrigue@hofstra.edu \\ THEO NOTTEBOOM \\ Institute of Transport \& Maritime Management Antwerp (ITMMA), \\ University of Antwerp, Kipdorp 59, B-2000 Antwerp, Belgium \\ And \\ Antwerp Maritime Academy \\ E-mail: theo.notteboom@.ua.ac.be
}

\begin{abstract}
The development of inland freight distribution systems has been an active strategy to promote the hinterland of maritime gateways around the world. While differences can be observed among North-American and European hinterlands, intermodal rail and dry ports are playing a key role in the process of port regionalization. Despite a growing level of attention on the context and setting of dry ports, the function these nodes perform within their respective hinterlands varies substantially in terms of their governance, the stakeholders and the commercial relations they support.

This paper analyzes the setting and development of rail-based dry ports in North America and Europe. We argue that rail-induced dry port development, or alternatively dry port induced rail development, comes in many forms and shapes as a function of the regional and local governance and regulatory settings, types and strategies of stakeholders involved, the spatial and functional relations with adjacent and or distant gateway ports, the dynamics in logistics network configurations, and the specific competitive setting (i.e. competition with trucking and barges in Europe) and imperatives in rail operations.
\end{abstract}

Keywords: Dry Ports, Inland Terminals, Rail, Freight Distribution, North America, Europe 


\section{INTRODUCTION}

Inland distribution has become a very important part of globalization, seaborne transportation and freight distribution and a cornerstone in port competitiveness (CEMT, 2001). Transport development is gradually shifting inland after a phase that focused on the development of port terminals and maritime shipping networks. In many places around the world bimodal and trimodal terminal facilities in the hinterland have become an intrinsic part of the transport system, particularly in regions having a high reliance on trade. These nodes in the hinterland networks of seaports have been referred to as dry ports, inland terminals, inland ports, inland hubs, inland logistics centres, inland freight villages, inland clearance depots, inland container depots, intermodal freight centers and inland freight terminals (Jaržemskis and Vasiliauskas, 2007; Roso, 2005; Cardebring and Warnecke, 1995; Roso et al., 2009 and Wiegmans et al., 1999). Thus, there seems no consensus on the terminology to be used.

Academic research on dry ports has grown exponentially in recent years as exemplified by the special issues on dry ports in Maritime Economics and Logistics (vol. 14, 2012) and Research in Transportation Economics (vol. 33, 2011). The first mention of dry ports in academic literature goes back to 1980 (Munford, 1980). A United Nations text of 1982 provides an early definition of the dry port concept: 'an inland terminal to which shipping companies issue their own import bills of lading for import cargoes assuming full responsibility of costs and conditions and from which shipping companies issue their own bills of lading for export cargos'. In this paper we follow the definition of Roso (2005) and Roso et al. (2009): 'a dry port is an inland intermodal terminal directly connected to seaport(s) with high capacity transport mean(s), where customers can leave/pick up their standardised units as if directly to a seaport'.

There are many reasons behind the growing attention for dry port development. The complexity of modern freight distribution, the increased focus on intermodal and co-modal transport solutions and capacity issues appear to be the main drivers. While trucking tends to be sufficient in the initial phase of the development of inland freight distribution systems, at some level of activity, diminishing returns such as congestion, energy consumption and empty movements become strong incentives to consider the setting of inland terminals as the next step in regional freight planning. Also the massification of flows in networks, through a concentration of cargo on a limited set of ports of call and associated trunk lines to the hinterland, have created the right condition for nodes to appear along and at the end of these trunk lines. The development of dry ports is in line with the port regionalization process, which is the latest stage of port and port system development and characterized by the expansion of the hinterland accessibility through market strategies and policies (Notteboom and Rodrigue, 2005).

The evolution of inland freight distribution can be seen as a cycle in the ongoing developments of containerization and intermodal transportation. The geographical characteristics linked with modal availability, capacity and reliability of regional inland access have an important role to play in shaping this development. As maritime shipping networks and port terminal activities become better integrated, particularly through the symbiotic relationship between maritime shipping and port operations, the focus shifted on inland transportation and inland terminal facilities and dry ports as a fundamental components of this strategy. Thus, after a phase that relied on the development of port terminals and maritime shipping networks, the integration of maritime and inland freight 
distribution systems has favored the setting of dry ports.

Rail accessibility to gateway seaports is at the heart of the functioning and development of most dry ports around the world. This paper analyzes the setting and development of rail-based dry ports in North America and Europe. We argue that rail-induced dry port development, or alternatively dry port induced rail development, comes in many forms and shapes as a function of the regional and local governance and regulatory settings, types and strategies of stakeholders involved, the spatial and functional relations with adjacent and or distant gateway ports, the dynamics in logistics network configurations, and the specific competitive setting (i.e. competition with trucking and barges in Europe) and imperatives in rail operations.

The paper is structured as follows: in the first three sections we analyse the driving forces for rail-based dry port development and the role of dry ports in transport and supply chains. Then, we analyze rail and gateway port development in North America and Europe in search of distinctive characteristics and differences that could have an impact on dry port development. In the next section we provide an assessment of dry port development in both continents. The last section contains the conclusions and explores avenues for further research.

\section{DRIVING FORCES FOR RAIL-BASED DRY PORT DEVELOPMENT}

Each dry port remains the outcome of the considerations of a transport geography pertaining to modal availability and efficiency, market function and intensity as well as the regulatory framework and governance. The geographical characteristics linked with modal availability and the capacity of regional inland access have an important role to play in shaping the emergence and development of dry ports. Each inland market has its own potential requiring different transport services. Thus, there is no single strategy for a dry port in terms of modal preferences as the regional effect remains fundamental.

The setting of global supply chains and the strategy of Pacific Asian countries around the export-oriented paradigm have been powerful forces shaping contemporary freight distribution. Indirectly, this has forced players in the freight transport industry (shipping companies, terminal operators, logistics providers) to examine supply chains as a whole and to identify legs where capacity and reliability were an issue. Once maritime shipping networks and port terminal activities have been better integrated, particularly through the symbiotic relationship between maritime shipping and port operations, inland transportation became the obvious focus and the inland terminal a fundamental component of this strategy. This initially took place in developed countries, namely North America and Western Europe, which tended to be at the receiving end of many containerized supply chains and thus focused on inbound logistics. The focus has also shifted to considering inland terminals for the early stages of global supply chains (outbound logistics), namely in countries having a marked export-oriented function.

Inland terminals have evolved from simple intermodal locations to their incorporation within logistic zones. Inland terminals (particularly rail) have always been present since they are locations from which specific market coverage is achieved. Containerization has impacted this coverage through the selection of terminals that were servicing a wider 
market area. This spatial change also came with a functional change as intermodal terminals began to experience a specialization of roles based on their geographical location but also based on their 'location' within supply chains. Three fundamental characteristics are related to an inland node:

- An intermodal terminal (rail/truck, barge/truck or trimodal) that has been built or expanded;

- A connection with a port terminal through rail, barge or truck services, often through a high capacity corridor;

- An array of logistical activities that support and organize the freight transited, often co-located with the intermodal terminal.

The functional specialization of dry ports has been linked with cluster formation of logistical activities. Dry ports in many cases have witnessed a clustering of logistics sites in the vicinity, leading to a process of logistics polarization and the creation of logistic zones. They have become excellent locations for consolidating a range of ancillary activities and logistics companies. In recent years, the dynamics in logistics networks have created the right conditions for a large-scale development of such logistics zones.

In addition to standard capacity and accessibility issues in the hinterland, a dry port is a location actively integrated within supply chain management practices, particularly in view of containerization. This takes many forms such as the agglomeration of freight distribution centers, custom clearance, container depots and logistical capabilities. The dry port can also become a buffer in supply chains, acting as a temporary warehousing facility often closely connected to the warehouse planning systems of nearby distribution centers (Rodrigue and Notteboom, 2009). Purchasers can even be advantaged by such a strategy since they are not paying for their orders until the container leaves the terminal, delaying settlement even if the inventory is nearby and available.

The emergence of dry ports in some cases underlines some deficiency in conventional inland freight distribution that needed to be mitigated. First, when a deep sea terminal facility has limited land available for expansion, the intensification of activities at the main terminal triggers a search of lower land value locations supporting less intensive freight activities. Second, capacity problems in seaport areas appear to be one of the main drivers of dry port development since a system of inland terminals increases the intermodal capacity of inland freight distribution. Third, through long distance transport corridors, dry ports confer a higher level of accessibility because of lower distribution costs and improved capacity. These high-capacity inland transport corridors allow ports to penetrate the local hinterland of competing ports and thus to extend their cargo base.

\section{THE FUNCTION OF DRY PORTS WITHIN TRANSPORT CHAINS}

A functional and added value hierarchy has emerged for dry ports. In many instances, freight transport terminals fit within a hierarchy with a functionally integrated inland transport system of gateways and their corridors, where they service three major functions. 


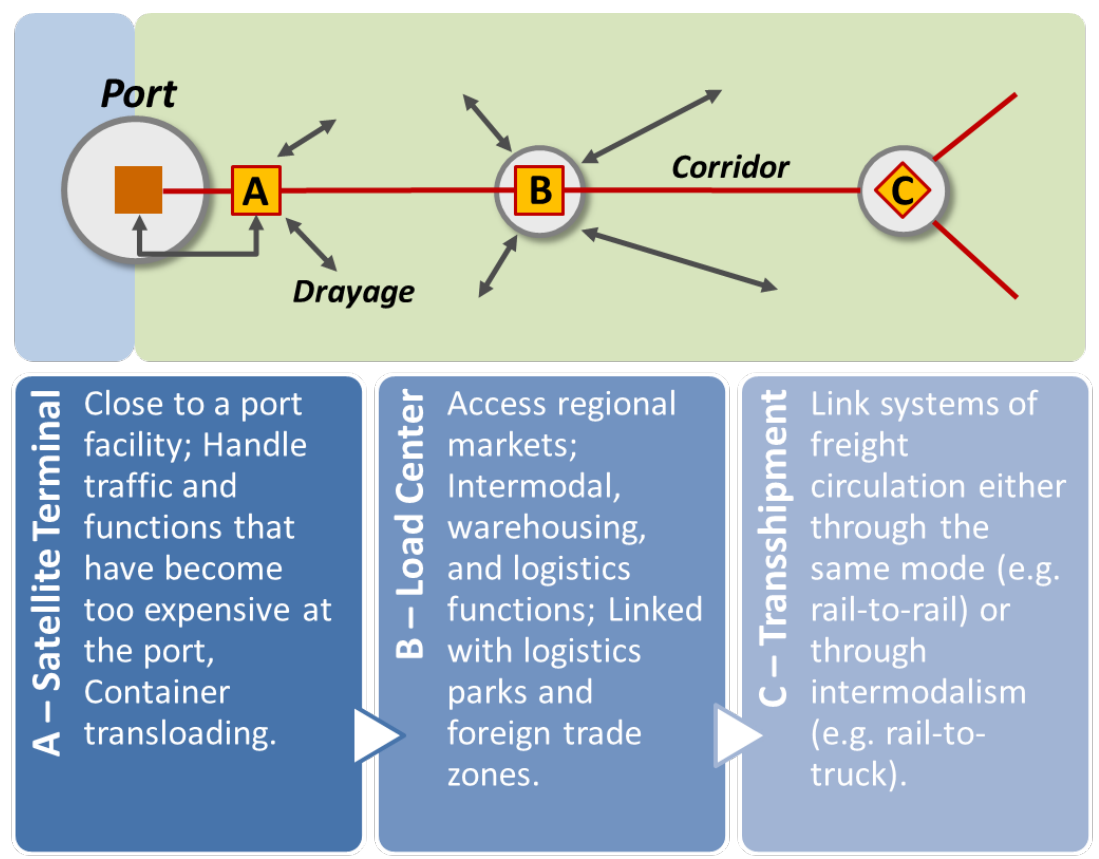

Satellite terminals tend to be close to a port facility, but mainly at the periphery of its metropolitan area (often less than $100 \mathrm{~km}$ ), since they mainly assume a service function to the seaport facilities. They accommodate additional traffic and serve functions that either have become too expensive at the port such as warehousing and empty container depots or are less bound to a location near a deep sea quay. A number of satellite terminals only have a transport function transshipping cargo from rail/barge to trucks and vice versa, as is the case for the 'container transferium' concept of the port of Rotterdam or the Gateway Access Point (GAP) concept in Belgium. Satellite terminals can also serve as load centers for local or regional markets, particularly if economic density is high, in which case they form a multi-terminal cluster with the main port they are connected to through regular rail or barge shuttle services. For gateways having a strong import component, a satellite terminal can also serve a significant transloading function where the contents of maritime containers are transloaded into domestic containers or truckloads.

Freight distribution clusters (load centers) are major intermodal facilities granting access to well defined regional markets that include production and consumption functions. It commonly corresponds to a metropolitan area where a variety of terminals serve concomitantly intermodal, warehousing, distribution and logistics functions. These tend to take place in logistics parks and free trade zones (or foreign trade zones). The inland terminal is thus the point of collection or distribution of a regional market. The more extensive and diversified the market, the more important is the load center. If the load center has a good intermediary location, such as being along a major rail corridor, then freight distribution activities servicing an extended market will be present.

Transshipment facilities link large systems of freight circulation either through the same mode (e.g. rail-to-rail) or through intermodalism (rail-to-truck, or even rail-to-barge). In the latter case, the inland terminal assumes the role of a load center. The origin or the destination of the freight handled is outside the terminal's market area, a function similar to that of transshipment hubs in maritime shipping networks. Such transshipment terminals are often found near country borders in view of combining administrative processes linked 
to cross border traffic to value-added logistics activities. Although this function remains marginal in most parts of the world, ongoing developments in inland freight distribution, where the scale and scope of intermodal services are increasing, are indicative that transshipment services are bound to become more prominent.

These functions are not exclusive, implying that inland terminals can service several functions at once. There is therefore no single model for a dry port. For inbound or outbound freight flows, the inland terminal is the first tier of a functional hierarchy that defines its fundamental (activities it directly services) and extended (activities it indirectly services) hinterlands.

\section{THE FUNCTION OF DRY PORTS WITHIN SUPPLY CHAINS}

Considering the potential mix of the functions of dry ports, five major criteria insure that they fulfill efficiently their role as an interface between global and regional freight distribution systems:

\section{Site and situation}

Like any transport facility of significance, an inland port requires an appropriate site with good access to the rail or the barge terminal as well as available land for development. Access to a large population base is of importance since it will be linked to the level of import and export activities handled by the inland port. Transportation remains the most significant logistics cost, underlining the importance of an accessible location. Under such circumstances, distributors are willing to pay higher rents to take advantage of a logistics site that offers co-location with an intermodal terminal since this strategy enables them to reduce transportation costs, such as drayage, as well as improve their time responsiveness (lead time). Several dry ports also have an airport in proximity which can help support a variety of freight activities.

\section{Repositioning}

Since most long distance trade (and some domestic) is supported by containerization, there are numerous instances where a regional market imports more than it exports (or vice-versa). Under such circumstances, an inland port must provide the physical and logistical capabilities to insure that empty containers are repositioned efficiently to other markets if local cargo cannot be found. This can take the form of empty container depots and arrangements with freight forwarders to have slots available for repositioning.

\section{Cargo rotation}

Whether there are imbalances in container flows or not, an inland port must insure that the inbound and outbound flows are reconciled as quickly as possible. A common way involves a cargo rotation from imports activities where containers are emptied to exports activities where containers are filled with goods. For container owners, let them be maritime shipping or leasing companies, a rapid turnover of their assets is fundamental and will secure a continuous usage of the inland port. Effective repositioning and cargo rotations strategies will insure higher revenue levels for both the container owners and the dry port operators.

\section{Trade facilitation}


An inland port can also be a fundamental structure promoting both the import and export sectors of a region, particularly for smaller businesses unable to achieve economies of scale on their own. The hinterland massification opportunities offered by inland ports are associated with lower transport costs and a better accessibility. Through these, new market opportunities become possible as both imports and exports are cheaper.

\section{Governance}

The way a dry port is owned and operated is indicative of its potential to identify new market opportunities and invest accordingly. In many cases, the commitment of a large private investor such as a port operator or a real estate developer can be perceived as a risk mitigation strategy in addition to provide expertise in the development of facilities and related activities. Sections of a dry port can be shared facilities (e.g. distribution centers) so that smaller players can get involved by renting space and equipment. This also applies to the appropriate strategies related to each stage in the life cycle of an inland terminal from its construction to its maturity where its potential has essentially been taped off. The setting of a Foreign Trade Zone (FTZ) is also an option to be considered. Dry ports and their associated logistic zones have a wide range of options in terms of their governance model. The ownership and the management of a dry port can be public, private or a combination of both. Since dry ports are long term projects that are unlikely to be profitable in their initial phase, they represent a high risk for private investors. Since among the benefits of inland ports are job creation and a better usage of regional transport infrastructures, they tend to be perceived as projects of public benefit.

Table 1 : Main Governance Models for Inland Ports

\begin{tabular}{|c|c|c|}
\hline Model & Characteristics & Implications \\
\hline Single ownership & $\begin{array}{l}\text { A public or a private actor entirely } \\
\text { responsible for development and } \\
\text { operations. } \\
\text { Single vision and conformity to a } \\
\text { specific role. }\end{array}$ & $\begin{array}{l}\text { Potential lack of flexibility in view to } \\
\text { changes (single mandate). } \\
\text { Potential conflicts with surrounding } \\
\text { communities. }\end{array}$ \\
\hline $\begin{array}{l}\text { Public - Private } \\
\text { Partnership }\end{array}$ & $\begin{array}{l}\text { Help combine public planning of } \\
\text { infrastructures with private } \\
\text { operational expertise. } \\
\text { Public (local) interests represented }\end{array}$ & $\begin{array}{c}\text { Tendency to prioritize public interests over } \\
\text { private interests. }\end{array}$ \\
\hline Landlord model & $\begin{array}{l}\text { Public ownership and private } \\
\text { operations (a form of PPP). } \\
\text { Long term concession agreements. }\end{array}$ & $\begin{array}{c}\text { Managerial flexibility between the owner, } \\
\text { the site manager and the operators. } \\
\text { Most of the risk assumed by private } \\
\text { operators. }\end{array}$ \\
\hline
\end{tabular}

Source : adapted from Slack and Comtois (2010)

\section{RAIL TRANSPORT IN EUROPE AND NORTH AMERICA}

A rail-based dry port combines a railway terminal facility with surrounding logistics and distribution activities and is well connected to one or more gateway ports. In order to understand the governance setting and market environment for dry port development in Europe and North America, it is essential to understand how the rail markets in both continents are organized, which logistics and distribution concepts are being applied and how the container port/gateway system is configured. In this section we elaborate on the 
rail freight markets while the next section brings the essentials on distribution systems and seaport systems in containerized freight.

The container rail market in North America has been heavily affected by a significant deregulation that unfolded since the 1970s. The Staggers Act(1980) proved to be a key piece of legislation in the competitiveness of transport by rail. The act liberated rate setting, relaxed common carrier obligations and simplified merger applications (Dennis, 2000). The deregulation process resulted in productivity and volume increases, lower rates and a strong market consolidation through mergers and acquisitions. The North American rail transport system is very extensive, but at the same time shows a high level of geographical specialization with seven large rail carriers servicing vast regional markets (Rodrigue, 2008).

Each carrier has its own facilities and railway tracks and thus its own markets along the segments it controls. The rail system is the outcome of substantial capital investments occurring over several decades with the accumulation of impressive infrastructure and equipment assets. The system was developed to support commodity flows, particularly coal and grain. Competition has a strong regional connotation where over vast tracks of territory only two rail operators have intermodal terminals. However, the growth of intermodalism created issues about continuity within the North American rail network, particularly in the United States. Mergers have improved this continuity but a limit has been reached in the network size of most rail operators. Attempts have been made to synchronize the interactions between rail operators for long distance trade with the setting of intermodal unit trains. Often bilateral, trilateral or even quadrilateral arrangements are made between rail carriers and shipping companies to improve the intermodal interface at the major gateways or at points of interlining between major networks.

Chicago is the largest interlining center in North America, handling around 10 million TEU per year, a location at the junction of the Eastern (NS and CSX), Western (UP, BNSF and KCS) and Canadian rail systems (CN and $\mathrm{CP})$. Other significant interlining locations include Kansas City, St. Louis and Memphis. In container transport, the double stack train arguably is the most visible characteristic of the North American intermodal system. Double stack trains gave significant economies of scale and gained a significant cost advantage over the trailer on flat car system (TOFC). The double stack rail network benefited from the introduction of post-Panamax vessels on the Trans-Pacific trade route in the late 1990s. The limitation of the Panama Canal locks made the combination of a call of a post-Panamax container vessel at a West Coast container port plus onward transport by double stack train a valuable option, compared to the all-water route (with panamax vessels of up to 5,000 TEU) from Asia to the US East Coast via the Panama Canal. The expansion of the Panama Canal with a new set of larger locks scheduled to open in 2014 is likely to change the intermodal balance within the North America market, mostly by making the all-water route most cost effective and thus expanding the hinterland of East Coast ports.

The development of container transport by rail in Europe has been strongly effected by EU policies focused on European integration and a rail deregulation process. Before the early 1990s a geographically, politically and economically fragmented Europe prevented the realization of a greater European-wide integrated intermodal rail network (Charlier and Ridolfi, 1994). Since the mid-1990s the European intermodal sector has undergone major changes as a result of European rail liberalization and with it the entry of new market players (see e.g. Gouvernal and Daydou, 2005 and Debrie and Gouvernal, 2006). The 
emergence of a new generation of rail operators not only made incumbent firms (i.e. mostly former national railway companies) act more commercially, but also led to the improvement in the endogenous capabilities of the railway sector. This in time could make rail a more widespread alternative in serving the European hinterlands, although technical and operational issues facing cross-border services continue to hamper the efficiency of international container trains (e.g. the standardization of rail traffic management systems under the ERTMS scheme - European Rail Traffic Management System). At present, a wide array of rail operators make up the supply of rail products out of European container ports. The largest players include DB Schenker Rail and SNCF but many smaller players are also offering services ${ }^{1}$.

Hamburg's rail connections outperform all other ports in numbers (more than 160 international and national shuttle and block train services per week) and in traffic volumes by rail (1.89 million TEU in 2008). Rotterdam (rail volume of 1 million TEU in 2008) and Antwerp (837,000 TEU) each have between 150 and 200 intermodal rail departures per week. Other European seaports with substantial rail volumes include Bremerhaven (867,000 TEU), Zeebrugge (675,000 TEU), Gothenburg (342,000 TEU) and La Spezia (300,000 TEU). Still, rail transport typically represents a small share in the land-based container flows of many European containers ports with German seaports and Zeebrugge as the notable exceptions (Table 2). Smaller container ports tend to seek connection to the extensive hinterland networks of the large seaports by installing shuttle services either to rail platforms in the big container ports or to rail hubs in the hinterland.

Table 2: Modal split in land-based container flows of some major European container ports

\begin{tabular}{lcccc}
\hline Seaport & $\begin{array}{c}\text { Total container } \\
\text { throughput (including } \\
\text { sea-sea transshipment) }\end{array}$ & Road & Rail & $\begin{array}{c}\text { Inland } \\
\text { barge }\end{array}$ \\
\hline Antwerp (Belgium) & Million TEU & $\%$ & $\%$ & $\%$ \\
Bremerhaven (Germany) & 8.66 & 56.6 & 11.0 & 32.4 \\
Constanza (Romania) & 5.50 & 34.0 & 62.9 & 3.1 \\
Hamburg (Germany) & 1.38 & 69.6 & 27.8 & 2.6 \\
Le Havre (France) & 9.70 & 63.1 & 34.7 & 2.2 \\
Marseille (France) & 2.45 & 86.2 & 6.6 & 7.2 \\
Rotterdam (the Netherlands) & 0.85 & 81.0 & 13.0 & 6.0 \\
Zeebrugge (Belgium) & 10.83 & 57.0 & 13.0 & 30.0 \\
\hline
\end{tabular}

Source: own compilation based on data from respective port authorities and Schiffahrt Hafen Bahn und Technik, No. 1 (2010), p. 68

From a network perspective, intermodal rail transport in Europe has undergone a transition from a meshed network to a star or hub-and-spoke network based on intermediate rail hubs and then finally the replacement of the network by a system of direct lines. For example, the backbone of rail services out of the main European container ports is formed by direct

\footnotetext{
${ }^{1}$ For example, the Netherlands counts 14 licensed railway undertakings: DB Schenker Rail NL (the former national railway company NS, now part of DB Schenker), ACTS, ERS, Rail4Chem, Rotterdam Rail Feeding, Veolia-Cargo, B-Cargo, Fret SNCF, ITL, CTL, HGK, Crossrail, etc.. Belgium counts 10 licensed operators: B-Cargo (former national railway company), Crossrail Benelux, Trainsport AG, ACTS, RRF, SNCF Fret, Veolia Cargo, ERS, CFL-Cargo and DB Schenker Rail NL.

2 Modal split figures for terminal operator Eurogate only.
} 
point-to-point shuttle trains with a unit capacity ranging from 40 to 95 TEU per shuttle (Notteboom, 2008). However, the profitability of a lot of individual direct shuttle trains even to the immediate hinterland of European load centre ports remains uncertain. In the past some carriers and rail operators have resolved the problems related to the fluctuating volumes and the numerous final destinations by bundling container flows in rail hubs in the immediate hinterland. Numerous hub-and-spoke railway networks emerged in the 1990s. An example was the Qualitynet of Intercontainer-Interfrigo (ICF) with Metz-Sablon in north-eastern France as intermediate rail hub linking up the Rhine-Scheldt Delta ports with the rest of Western Europe. Such hub-and-spoke networks were revealed to be vulnerable, as the volumes on the spokes could be affected by (a) newcomers entering the market in the aftermath of European rail liberalization and (b) increasing intermodal volumes in seaports (Kreuzberger, 2005; Notteboom, 2009). New railway operators often "cherry-pick" by introducing competing direct shuttle trains on a spoke of a competitor's established hub-and-spoke network. This has a negative effect on cargo volumes on the spoke and can lead to a collapse of the whole hub-and-spoke system. That is what happened to ICF's Qualitynet in 2004. ICF launched its new strategy in December 2004. The intermodal traffic of the former Qualitynet hub in Metz is now handled by a set of direct shuttle trains going to fewer destinations. For eastern and south-eastern Europe, services are centered around the hub in Sopron (Hungary). Rail hubs are progressively being abandoned. Nevertheless, some of the new systems being set up by operators still include massification centres. For instance, German intermodal operator BoxXpress uses Gmunden in Germany to connect trains leaving from Bremerhaven and Hamburg. However, these types of terminals are only massifying gateways on direct routes and do not act as intermediate hubs for a large number of spokes.

Table 3: Differences between the North American and European container rail networks

\begin{tabular}{|c|c|c|}
\hline & North America & Western Europe \\
\hline Market dynamics & $\begin{array}{l}\text { Fully liberalized since the } 1980 \text { s. Introduction } \\
\text { of double stack technology as key development. }\end{array}$ & $\begin{array}{l}\text { Liberalization process since early } 1990 \text { s. } \\
\text { Cross-border operations facilitated by corridor } \\
\text { concept and Rail Net Europe. }\end{array}$ \\
\hline $\begin{array}{l}\text { Primary focus of } \\
\text { the rail network }\end{array}$ & Freight (dry bulk, containers, TOFC) & Passengers \\
\hline Governance & $\begin{array}{l}\text { Private ownership and operations of } \\
\text { infrastructure and rail services }\end{array}$ & $\begin{array}{l}\text { Separation of infrastructure management } \\
\text { (public) and rail operations (public or private) }\end{array}$ \\
\hline Market players & Consolidation to a handful of operators. & $\begin{array}{l}\text { End of monopoly of national railway } \\
\text { companies. Consolidation (cf. DB Schenker } \\
\text { Rail), but also entry of new smaller players. }\end{array}$ \\
\hline Service area & $\begin{array}{l}\text { Each operator has a specific service area (East, } \\
\text { West or Canada). }\end{array}$ & $\begin{array}{l}\text { Creation of trans-European railway operations } \\
\text { by largest players (DB, SNCF); more niche } \\
\text { markets for smaller players. }\end{array}$ \\
\hline Distances & $\begin{array}{l}\text { Double stack trains cover distances of up to } \\
3000 \mathrm{~km} \text {. }\end{array}$ & $\begin{array}{l}\text { Typically between } 300 \text { and } 1500 \mathrm{~km} \text {, while } \\
\text { shorter shuttle trains mainly exist in inter-port } \\
\text { traffic. }\end{array}$ \\
\hline Train capacity & 300-500 TEU per double stack train $(*)$ & 40-95 TEU using flat cars \\
\hline Network structure & $\begin{array}{l}\text { Direct shuttle trains bundled around major } \\
\text { interlining hubs (Chicago, Kansas City, St. } \\
\text { Louis and Memphis) }\end{array}$ & $\begin{array}{l}\text { Direct shuttle trains where possible. } \\
\text { Hub-and-spoke network where needed (e.g. in } \\
\text { connection to East/Central Europe) }\end{array}$ \\
\hline
\end{tabular}

(*) The longest double stack train ever was a Union Pacific train (2009) counting 287 wagons or some 1,150 TEU. 
There are a number of noticeable differences between the North American and European rail networks (Table 3). Next to factors already discussed, it is worth mentioning that the European railway network is very much focused on passenger transport, not only through a dense network of commuter trains but also via a growing high speed network. With a few exceptions (such as the Betuweroute between the port of Rotterdam and the Dutch/German border), freight and passenger trains use the same infrastructure, with the latter having the highest priority. The lack of dedicated tracks for freight transportation complicates the allocation of train slots to container shuttle trains, particularly in the main seaport regions of Europe. In contrast, the influence of passenger transport on North American double stack trains is very small. Another key difference relates to the governance system in place. Railway companies in North America act as both infrastructure owner and rail service operator. The rail liberalization process in Europe has led to a separation between infrastructure management and railway operations. Railway undertakings now have to deal with the relevant rail infrastructure managers for acquiring the necessary train paths to run national or cross-border shuttle trains. The railway undertakings pay an infrastructure charge per tonkm to the infrastructure managers. Rail Net Europe (RNE) groups 37 railway infrastructure managers in Europe. The Path Coordination System of RNE aims to provide one-stop-shop solutions for pre-constructed paths on a set of European railway corridors, while the Charging Information System (CIS) gives information on the charges linked to cross-border train paths. Thus, the European rail network faces a lot of coordination issues among infrastructure managers and between infrastructure managers and users.

\section{DISTRIBUTION SYSTEMS AND GATEWAYS IN EUROPE AND NORTH AMERICA}

Rodrigue and Notteboom (2010) and Notteboom (2010) provide an extensive analysis of distribution systems and related multi-port gateway port regions in Europe and North America. The main points are summarized in table 3. When it comes to the distribution of overseas goods (inbound logistics), a general distribution structure does not exist. Both in Europe and North America the conventional distribution networks shifted from a system of regional or even local distribution centers to central Gateway Distribution Center (GDC): in Europe typically a European Distribution Center (EDC) covering all European Union countries and, in North America, a large distribution center servicing a part of the continent, often divided by coast. In some market segments, local market demand has led companies to opt for Regional Distribution Centers or RDCs. Companies today often opt for a hybrid distribution structure of centralized and local distribution facilities. For instance, they use a GDC for medium- and slow-moving products and RDCs for fast-moving products. These RDCs typically function as rapid fulfillment centers rather than holding inventories. The choice between the various distribution formulas depends on among other things the type of product, the variability in demand for the product and the frequency of deliveries. At present, the majority of EDCs in Europe is still opting for a location in the Benelux region or northern France, but more and more regions are vying for a position as attractive location for RDCs and potentially EDCs. In Europe, inland distances are more limited, so maritime containers tend to move directly to their bound distribution centers through inland ports. In North America, gateway distribution centers are dominantly around the 
Los Angeles / Long Beach, New York / New Jersey and Savannah clusters.

Table 4: Comparison of gateway logistics in North America and Europe

\begin{tabular}{|c|c|c|c|}
\hline & North America & Western Europe & Trend \\
\hline $\begin{array}{l}\text { Distribution } \\
\text { systems for } \\
\text { import cargo }\end{array}$ & $\begin{array}{l}\text { GDCs often divided per } \\
\text { coast }\end{array}$ & $\begin{array}{l}\text { EDC (mainly in Benelux) and } \\
\text { EDC/RDC configurations are } \\
\text { dominant }\end{array}$ & Triple/double EDC for Europe. \\
\hline \multirow{3}{*}{$\begin{array}{l}\text { Gateways - } \\
\text { location and } \\
\text { function }\end{array}$} & \multirow[t]{3}{*}{ Near major markets } & $\begin{array}{l}\text { Coastal gateways linked to } \\
\text { logistical platforms. }\end{array}$ & In general status quo \\
\hline & & $\begin{array}{l}\text { Combination of gateway and } \\
\text { transhipment function. }\end{array}$ & $\begin{array}{l}\text { Convergence at level of logistical } \\
\text { platforms: increased development }\end{array}$ \\
\hline & & $\begin{array}{l}\text { Some 'pure' transhipment } \\
\text { hubs (particularly in Med) }\end{array}$ & $\begin{array}{l}\text { of inland logistical platforms in } \\
\text { North America }\end{array}$ \\
\hline \multirow{3}{*}{$\begin{array}{l}\text { Gateway } \\
\text { system }\end{array}$} & Concentrated & \multirow{2}{*}{$\begin{array}{l}\text { Fairly concentrated } \\
\text { (particularly in the Hamburg- } \\
\text { Le Havre range) }\end{array}$} & Divergence in concentration level \\
\hline & $\begin{array}{l}\text { Concentration level } \\
\text { increasing }\end{array}$ & & \multirow{2}{*}{$\begin{array}{l}\text { Future EU concentration level } \\
\text { partly subject to policy debate on } \\
\text { infrastructure/corridor } \\
\text { development. }\end{array}$} \\
\hline & $\begin{array}{l}\text { Limited number of } \\
\text { gateways }\end{array}$ & $\begin{array}{l}\text { Concentration level slightly } \\
\text { decreasing: more gateways } \\
\text { and entry of new gateway } \\
\text { regions (cf. Baltic }+ \text { Med) }\end{array}$ & \\
\hline \multirow[t]{2}{*}{ Corridors } & \multirow[t]{2}{*}{ Long distance rail } & $\begin{array}{l}\text { Short and medium distance } \\
\text { barge and truck. }\end{array}$ & \multirow[t]{2}{*}{$\begin{array}{l}\text { Some convergence, but no 'double } \\
\text { stack' and real landbridges in EU }\end{array}$} \\
\hline & & Medium-distance rail & \\
\hline \multirow[t]{2}{*}{ Hinterlands } & $\begin{array}{l}\text { Economies of scale at } \\
\text { terminals }\end{array}$ & $\begin{array}{l}\text { Economies of scale at } \\
\text { gateways. }\end{array}$ & $\begin{array}{l}\text { Convergence (more contested } \\
\text { hinterlands, inland ports) }\end{array}$ \\
\hline & $\begin{array}{l}\text { Large hinterlands both for } \\
\text { gateways and inland ports. }\end{array}$ & $\begin{array}{l}\text { Inland ports more constrained } \\
\text { (thus more of them). }\end{array}$ & $\begin{array}{l}\text { Convergence hindered by } \\
\text { ownership regulations (cf. EU: } \\
\text { split between } \\
\text { infrastructure/operations) }\end{array}$ \\
\hline \multirow[t]{3}{*}{ Governance } & \multirow{2}{*}{$\begin{array}{l}\text { Private ownership and } \\
\text { operations }\end{array}$} & Public ownership & Convergence towards PPPs \\
\hline & & Private operations & \multirow{2}{*}{$\begin{array}{l}\text { Reassessment of facilitating role of } \\
\text { governments in gateway logistics }\end{array}$} \\
\hline & $\begin{array}{l}\text { Low impact of } \\
\text { administrative borders }\end{array}$ & $\begin{array}{l}\text { Higher impact of } \\
\text { administrative borders in } \\
\text { gateway logistics development }\end{array}$ & \\
\hline
\end{tabular}

Source: adapted from Rodrigue and Notteboom (2010)

In North America, there is a high level of concentration of economic activities along coastal areas (East and West coasts) with significant resource and manufacturing hinterlands. Gateways tend to be the dominant markets and this for all the two major maritime facades, with the Gulf Coast playing a more marginal role, particularly for containers. North America relies on a relatively small number of gateways and less developed port ranges have few chances to fully take part in international shipping networks. Long Beach/Los Angeles are the major gateways along the Pacific Coast, mainly catering to Asian import cargo. Longitudinal long distance rail corridors, often taking the form of a landbridge, are servicing a continental hinterland articulated by major transportation and industrial hubs such as Chicago and Kansas City. The major changes in North America's hinterlands, namely the decline of the industrial belt (which has been monitored for decades) and the industrialization of the "sun belt" are long term shifts that are reflected in the gradual reorientation of the traffic. NAFTA also favors the setting of natural gateways and corridors, namely through Canada (in particular Vancouver and 
Montreal) and Mexico (Lazero Cardenas) and a reorientation of traffic flows (Brooks, 2008).

In Western Europe, the hinterland is not only intense along the coastline but also in the interior, notably along the Rhine river system and its tributary rivers (Main and Neckar), Bavaria in the South of Germany, the economics centers around Milan in Northern Italy and Madrid in central Spain and major markets in Paris, the Liverpool-Manchester-Leeds belt in the UK and the belt reaching from Austria to the growing production clusters in Hungary, the Czech Republic and Southern Poland. Moreover, large parts of the European economic centers are somewhat remote from the main shipping lanes as is the case for the countries around the Baltic. European gateways therefore act as intermediary locations to reach inland markets, even if many are important industrial centers (e.g. petrochemical industry). The hinterland is accessed from coastal gateways such as Rotterdam, Antwerp, Hamburg, Bremerhaven, Le Havre, Barcelona, Marseille and Felixstowe by medium distance corridors involving a variety of combinations of road, barge (where available) and rail services. Almost all the major European capitals are interior cities located along rivers. Cargo concentration levels in the European port system are slowly declining, whereby nearly all port ranges fully participate in international shipping networks and whereby each port range consists of a unique blend of load center ports and smaller facilities with a more local focus.

Although gateways are the fundamental structure of the maritime - land interface, terminals are the physical infrastructures through which functional regionalism is shaped. In the next section we discuss the emergence of new relations between port terminals and their hinterland with the setting of dry ports and distribution services in North America and Western Europe.

\section{DRY PORTS AND THEIR REGIONS}

Regional issues, namely how dry ports interact with their regional markets, remain fundamental as it defines their modal characteristics, their regulatory framework and their commercial opportunities. Depending on the geographical setting and the structure, governance and ownership of inland transport systems, dry ports have different levels of development and integration with port terminals.

\subsection{Western Europe}

It is in Western Europe that the setting of inland terminals is the most advanced with a close integration of port terminals with rail shuttles and barge services. European integration processes have permitted the setting of more natural (commercially based) hinterlands that did not exist before. Since a good share of the European market is inland, a growth in international trade required the setting of intermediary locations inland to help accommodate larger flows between ports and their hinterland. Local hinterland logistics are taking the form of emerging logistics poles consisting of a set of gateway ports and logistics zones in the immediate hinterland. A large concentration of dry ports can be found around the Rhine/Scheldt delta, which is Europe's most important gateway region with a total container throughput of 23.2 million TEU in 2011, and where the function of satellite terminals is prominent (Figure 2). Almost every European port has an inland terminal strategy as a way to secure hinterland traffic. 
A major concern in many European ports is the strong reliance of more local container volumes on trucks. While road haulage has always played a major role in shaping competition among load centres of the same multi-port gateway region for the immediate hinterland, intermodal transport is slowly but surely acquiring a strategic role as well. Regional trunk lines enhance the location of logistics sites in seaports and dry ports and along the axes between seaports and dry ports. Seaports are the central nodes driving the dynamics in such a large logistics pole. The rise of dry ports and associated logistics corridors enhanced port regionalization processes (Notteboom and Rodrigue, 2005). Logistics sites in the immediate hinterland typically greatly value the flexibility a multi-port gateway region offers in terms of available routing options for import and export cargo (Notteboom, 2010). In a logistics world confronted with mounting reliability and capacity issues, routing flexibility is a keystone for the logistics attractiveness of a region. For example, the logistics attractiveness of large parts of Belgium and the Netherlands for the location of European distribution centres (EDCs) is partly due to the existence of and high connectivity in several efficient gateways in the Rhine-Scheldt Delta.

Figure 2: Logistics polarisation in the Rhine-Scheldt Delta: logistics zones, trimodal dry ports, rail-based dry ports and barge-based dry ports

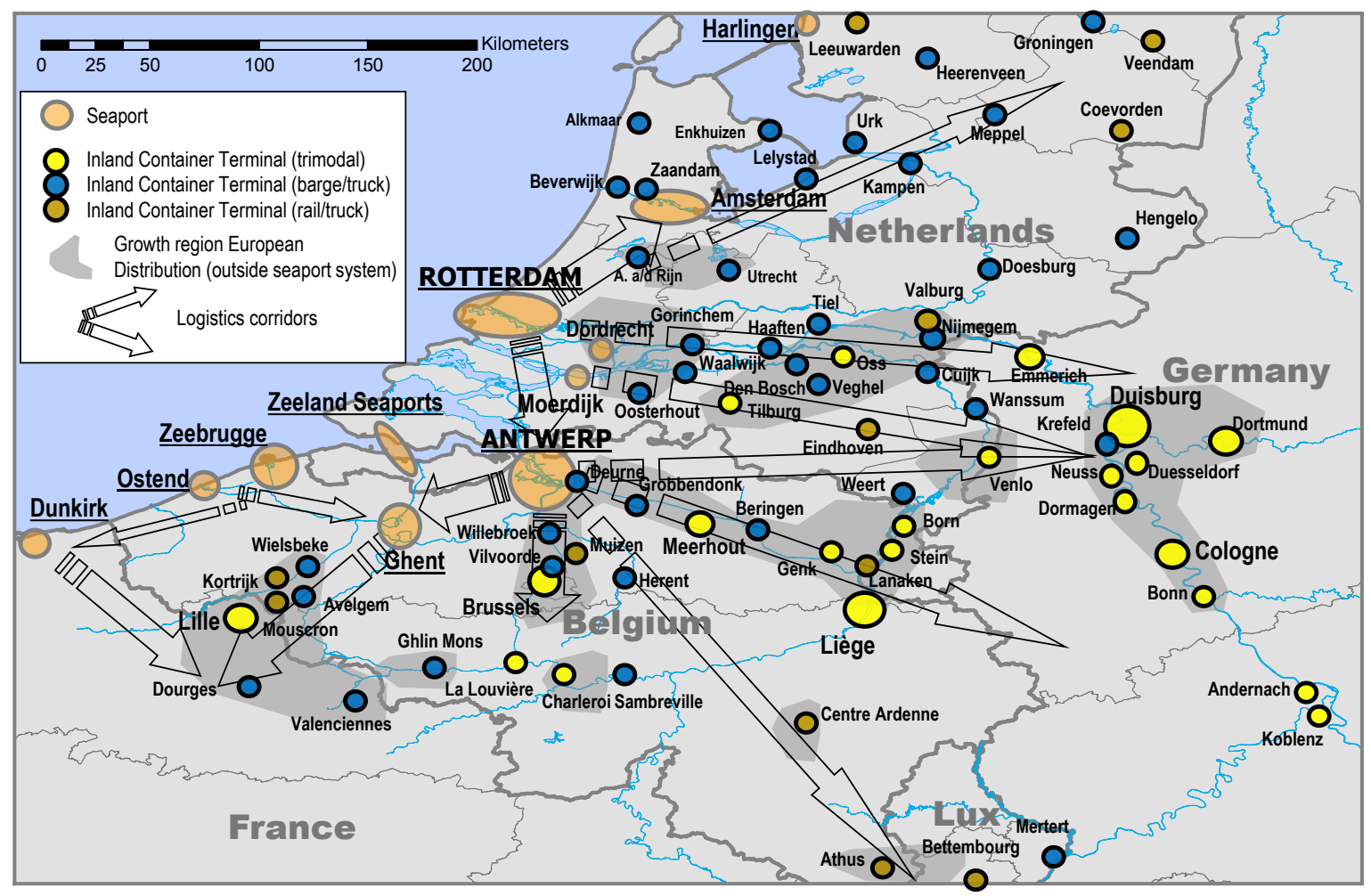

Source: updated and adapted from Notteboom (2000)

Rail-based dry ports are found throughout Europe, often linked to the development of logistics zones. The rail liberalization process in Europe is supporting the development of real pan-European rail services on a one-stop shop basis. All over Europe, new entrants are emerging while some large former national railway companies have joined forces. Rail terminals in Europe are mostly built and operated by large railway ventures. The largest rail facilities have bundles of up to 10 rail tracks with lengths of maximum $800 \mathrm{~m}$ per track. Rail hubs are typically equipped to allow simultaneous batch exchanges (direct transshipment) through the use of rail-mounted gantry cranes that stretch over the rail 
bundles.

In northwest Europe, rail networks and rail-based dry ports are being challenged by barge transport and bimodal barge/truck terminals which are taking up a very prominent role in dealing with gateway traffic, particularly in the Benelux, northern France and parts of Western Germany (see also modal split figures in table 2 and barge/truck terminals in figure 2). Barge container transport has its origins in transport between Antwerp, Rotterdam and the Rhine basin, and in the last decade it has also developed greatly along the north-south axis between the Benelux and northern France (Notteboom and Konings, 2004). Antwerp and Rotterdam together handled nearly 5 million TEU of inland barge traffic in 2010 or about $95 \%$ of total European container transport by barge. Promising barging developments are also found on the Seine between Le Havre and the Paris region, in the Rhône/Seine basin between Marseille, Lyon and Dijon, on the Elbe and the Weser in Northern Germany and on the Danube River out of the port of Constantza. Fluviomar recently started barge services on the Po River connecting the Port of Venice with Mantua and Cremona near Milan.

The increased focus on the hinterland gave impetus to specific coordination mechanisms among stakeholders (Van Der Horst and De Langen, 2008) and hinterland access regimes (De Langen and Chouly, 2004) in ports around Europe. Port authorities such as Rotterdam, Barcelona, Le Havre, Marseille, Antwerp and Lisbon all are actively enhancing processes of port regionalization (see Notteboom, 2009 for a more detailed analysis). Market players have developed specific concepts to reflect the growing function of inland terminals. For example, some terminal operators in Europe are increasing their influence throughout supply chains by incorporating inland terminals as 'extended gates' to seaport terminals (Rodrigue and Notteboom, 2009). Container terminal operator ECT in Rotterdam (part of Hutchison Port Holdings) follows an active strategy of acquiring key inland terminals acting as extended gates to its deepsea terminals (Veenstra et al., 2012). Through 'European Gateway Services', ECT offers shipping lines, forwarders, transport companies and shippers a variety of services to facilitate the optimal flow of containers between the deep-sea terminals in Rotterdam and the direct European hinterland. ECT bundles cargo, which allows for highly frequent inland barge and rail connections to various logistics hotspots in the European hinterland. Maersk Line wants to push containers into the hinterland supported by its terminal sister APM Terminals and its rail branch European Rail Shuttle (ERS). DP World uses the concept of 'terminal operator haulage' to streamline intermodal operations on the Seine and Rhône axes, while the large terminals of Antwerp Gateway (open since 2005) and London Gateway (open in 2012) are both linked to inland centres.

The advantages of the above solutions are substantial: customers can have their containers available in close proximity to their customer base, while the deepsea terminal operator faces less pressure on the deep-sea terminals due to shorter dwell times and can guarantee a better planning and utilization of the rail and barge shuttles. A close coordination with shipping lines, forwarders and shippers is needed to maximize the possibilities for the development of integrated bundling concepts to the hinterland. We argue that 'extended gate' and 'terminal operator haulage' strategies will increasingly evolve from point-to-point services (i.e. from a seaport to an inland port and vice versa) to network services which rely on routing flexibility offered via multiple inter-linked corridors. 


\subsection{North America}

There have been large inland terminals in North America since the development of the continental railway system in the late 19th century. Their setting was a natural process where inland terminals corresponded to large inland market areas, commonly around metropolitan areas commanding a regional manufacturing base and distribution system. Although exports were significant, particularly for agricultural goods, this system of inland terminals was mostly for domestic freight distribution. With globalization and intermodalism two main categories of inland terminals have emerged in North America.

The first is related to ocean trade where inland terminals are an extension of a maritime terminal located in one of the three major ranges (Atlantic, Gulf and Pacific) either as satellite terminals and more commonly as inland load centers (e.g. Chicago). The second category concerns inland terminals mainly connected to NAFTA trade that can act as custom pre-clearance centers. Kansas City can be considered the most advanced inland port initiative in North America as it combines intermodal rail facilities from four different rail operators, foreign trade zones and logistics parks at various locations through the metropolitan area. Like Chicago, the city can essentially be perceived as a terminal.

Figure 3: Main Trade Corridors, Dry Ports and Selected Co-Located Logistic Zones in North America

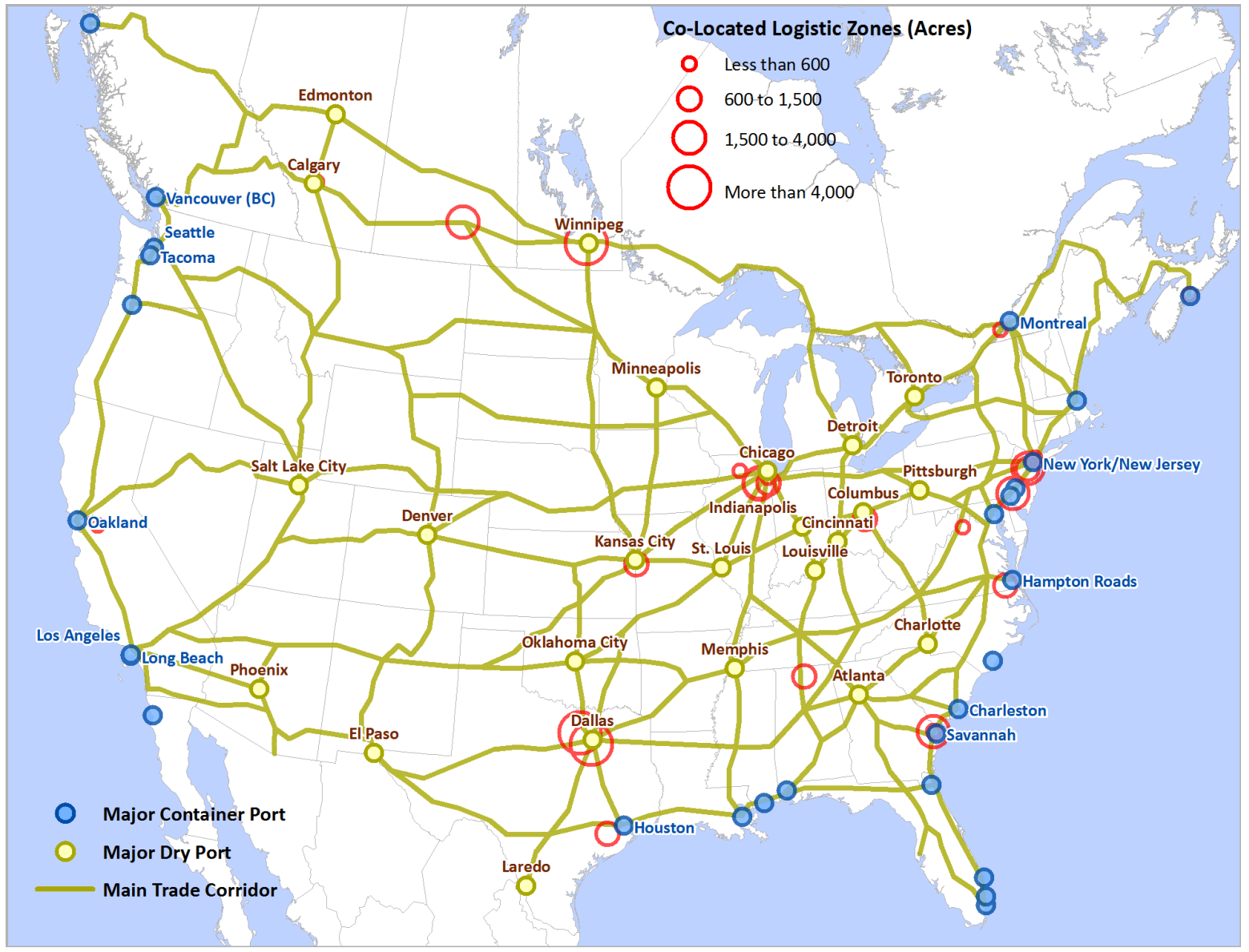

Compared to Europe, North American dry ports tend to be larger, but covering a much more substantial market area. Most of the North American dry ports initially developed 
were intermodal facilities acting as nodes of convergence for regional freight distribution enabling a modal shift away from road and freight diversion away from congested areas. These two key paradigms have been expanded with a more comprehensive approach leaning on the principle of co-location. As dry port projects become increasingly capital intensive and prone to risk because of their size, required equipment and infrastructure, the need for a higher value proposition is now set on the principle of co-location, many of which are public private partnerships. Several recent logistic zones projects in North America are capitalizing on the planning and setting of a new intermodal rail terminal done concomitantly with a logistics zone project (Figure 3Error! Reference source not found.). This co-location partnership fundamentally acts as a filter for the commercial potential of the project as both actors must make the decision to go ahead with their respective capital investment in terminal facilities and commercial real estate. The most common actors in a typical co-located dry port project involve a railway operator and a commercial real estate developer, or a local public development office.

The success of the co-location model in North America is linked to the market opportunities of the intermodal terminal through a set of value propositions:

- Real estate: Logistic zone projects tend to occupy a large amount of space to accommodate existing and anticipated freight distribution activities. Most co-located projects occupy at least 250 acres and several projects are well above 1,000 acres. Larger projects tend to have lower land acquisition costs. Also, since co-located projects involve at least two large players, a commercial real estate developer and a railway company, they are able to tap into capital pools with better conditions than a smaller actor (e.g. interest rates). For instance, CenterPoint Properties is owned by the pension fund CalPERS (California public employees' retirement fund), enabling access to long term capital pools. Another important aspect is that a co-located logistic project enables the joint planning of facilities.

- Specialization: A co-location project enables both actors involved to focus on their core competencies, creating multiplying factors. For instance, the rail company can focus on terminal development and operations while the real estate promoter can develop and manage the freight distribution facilities.

- Interdependency: both the terminal operator and freight distribution activities at the logistic zone are their respective customers, implying that both partners have vested interests in the efficiency of their operations. The possibility of joint marketing where the logistic zone is promoted as a single intermodal package is also common since the terminal is sold as a value proposition to potential customers.

- Drayage: a co-location project offers notable operational advantages for drayage, not just because of close proximity, but because trucks can have a priority access through the terminal's gates (e.g. pre-registration, advance notification, RFID). Drivers are able to perform more deliveries per day and the reliability of these deliveries improves.

- Asset utilization: Intermodal transportation assets are capital intensive and there are pressures to increase their utilization level to achieve better returns on investments. Containers and chassis tend to be the assets that are the most prone to such strategies, namely through the setting of chassis pools and empty container depots. 
- Information technologies: A co-location project offers the possibility to jointly plan information systems for terminal operations and the related supply chains, creating a community system where users can have access to real time information about the status of their shipments. Both terminal operations and their related supply chains benefit.

While co-location dry port projects have been particularly prevalent in North America, one drawback is that co-located logistics activities are dependent on the performance of the rail terminal as well as the level of service offered by the rail operator. If for any reason the rail operator has other priorities within its network, then the efficiency of the co-located logistic zone is compromised.

\section{CONCLUSION}

The setting of dry ports have been a dominant paradigm in the development of hinterland transportation as the growth of maritime transportation and its economies of scale have placed pressures on the inland segment of freight distribution. The prospects for dry ports remain positive with large continental markets like North America and Europe relying on a network of satellite terminals and load centers as a fundamental structure to support hinterland freight movements, particularly their massification. This entailed the emergence of extended gates and with them extended forms of supply chain management in which inland terminals play an active role. As the pressure on port regions increases in terms of freight flows passing through them and associated environmental effects, dry ports will be even more important in maintaining efficient and sustainable commodity chains. It can also be expected that resources will play a greater role within containerized trade with inland terminals, again underlining unique regional characteristics. This implies a set of repositioning strategies where inland terminals play a fundamental role either to improve the efficiency of this repositioning, by providing better cargo rotation opportunities, or by acting as an agent that can help promote containerized exports.

Dry ports will take part of the ongoing intermodal integration between ports and their hinterland through long distance rail and barge corridors. They are likely to be more important elements within supply chains, particularly through their role of buffer where containerized consignments can be cheaply stored, waiting to be forwarded to their final destinations.

Like several stages in intermodal transport development, such as in port infrastructure, there is a potential of overinvestment, duplication and redundancy as many inland locations would like to claim a stake in global value chains. This appears to be the case in Western Europe where an abundance of inland terminals, particularly within the Rhine / Scheldt delta, is indicative of an over competitive environment and the ambitions of local and regional authorities to become a logistics hubs in Europe. Also, the vulnerability of hub-and-spoke networks in rail transport makes the position of intermediate rail hubs uncertain: a shift to a system of direct shuttle trains might make the rail hub redundant and faces the logistics companies around the hub with a declining connectivity to gateway ports.

In North America, because of a different ownership and governance structure, the setting of a dry port, at least the intermodal terminal component, is mostly in the hands of rail 
operators. Each decision thus takes place with much more consideration being placed on market potential as well as the overall impact on their network structure. The decision of a rail company to build a new terminal or to expand existing facilities commonly marks the moment where regional stakeholders, from real estate developers to logistics service providers, readjust their strategies. In some instances, local governments will come with dry port strategies adjusting to existing commercial decisions in the hope to create multiplying effects.

The development of dry ports around the world has clearly underlined an emerging functional relation of port terminals and their hinterland. Based upon their regional setting, dry ports assume a variety of functions with co-location with logistical zones a dominant development paradigm. While the interest in dry ports has increased we have to be aware that no two dry ports are the same. Each dry port is confronted with a local/regional economic, geographical and regulatory setting which not only define the functions taken up by the dry port, but its relations vis-à-vis seaports. Best practices can only be applied successfully if one takes into account the relative uniqueness of each dry port setting.

\section{References}

Brooks, M. (2008) North American Freight Transportation: The Road to Security and Prosperity, Cheltenham, UK: Edward Elgar.

Cardebring, P.W. and C. Warnecke (1995) Combi-terminal and Intermodal Freight Centre Development, KFB-Swedish Transport and Communication Research Board, Stockholm.

Charlier J., Ridolfi, G. (1994) Intermodal transportation in Europe: of modes, corridors and nodes, Maritime Policy and Management, 21(3), 237-250.

CEMT (2001) Land Access to seaports, Round Table 113, CEMT, Paris

De Langen, P.W., Chouly, A. (2004) Hinterland Access Regimes in Seaports, European Journal of Transport \& Infrastructure Research, 4(4), 361-380.

Debrie, J., Gouvernal, E. (2006) Intermodal rail in Western Europe: actors and services in a new regulatory environment, Growth and Change, 37(3), 444-459.

Dennis, S.M. (2000) Changes in railroad rates since the Staggers Act, Transportation Research Part E, 37, 55-69

Gouvernal, E., Daydou, J. (2005) Container railfreight services in North-West Europe: diversity of organizational forms in a liberalizing environment, Transport Reviews, 25(5), $557-571$

Hayuth, Y. (1980) Inland container terminal function and rationale, Maritime Policy and Management, 7(4), 283-289.

Jaržemskis, A. and A. V. Vasiliauskas (2007) Research on dry port concept as intermodal node, Transport, 22(3), 207-213. 
Kreuzberger, E. (2005) Hub and spoking in a process of changing bundling concepts of intermodal rail networks: current developments in the light of intermodal efficiency, in: Witlox, F., Dullaert, W. and Vernimmen, B. (ed), Proceedings of the BIVEC-GIBET Transport Research Day 2005, Nautilis, Ghent, pp. 405-436

Leitner, S.J., Harrison, R. (2001) The identification and classification and inland ports, Center for Transportation Research, The University of Texas at Austin, Report 0-4083-1.

Munford C. (1980) Buenos Aires - congestion and the dry port solution. Cargo Systems International: The Journal of ICHCA, 7(10), 26-27.

Ng, A., Gujar, G.C. (2009) The spatial characteristics of inland transport hubs: evidences from Southern India", Journal of Transport Geography, 17(5), 346-356.

Notteboom, T. (2000) De invloed van ruimtelijke en logistieke ontwikkelingen in het voorland-achterlandcontinuüm op de positie en functie van zeehavens, RUCA, University of Antwerp: Antwerp, Ph.D. thesis, 724 p.

Notteboom, T. (2008) Bundling of freight flows and hinterland network development, in: Konings, R., Priemus, H., and Nijkamp, P. (eds), The Future of Intermodal Freight Transport, Operations, Technology, Design and Implementation, Edward Elgar: Cheltenham, pp. 66-88

Notteboom, T. (2009) The relationship between seaports and the intermodal hinterland in light of global supply chains: European challenges, Round Table no. 143, OECD International Transport Forum (ITF): Paris, pp. 25-75

Notteboom, T. (2010) Concentration and the formation of multi-port gateway regions in the European container port system: an update, Journal of Transport Geography, 18(4), $567-583$

Notteboom, T., Konings, R. (2004) Network dynamics in container transport by barge, Belgeo, 5(4), p. 461-477

Notteboom, T., Rodrigue, J-P (2005) Port regionalization: towards a new phase in port development, Maritime Policy and Management, 32(3), 297-313.

Notteboom, T., Rodrigue, J-P (2009) Inland Terminals within North American and European Supply Chains, Transport and Communications Bulletin for Asia and the Pacific, United Nations, Economic and Social Commission for Asia and the Pacific, No. 78, 1-57.

Rodrigue, J-P, Notteboom, T. (2009) The terminalization of supply chains: reassessing port-hinterland logistical relationships, Maritime Policy and Management, 36(2), 165-183.

Rodrigue, J-P, Notteboom, T. (2010) Comparative North American and European Gateway Logistics: The Regionalism of Freight Distribution, Journal of Transport Geography, 18(4), 497-507.

Rodriguem J-P (2008) "The Thruport Concept and Transmodal Rail Freight Distribution in North America", Journal of Transport Geography, Vol. 16, No. 4, pp. 233-246. 
Roso, V. (2005) The dry port concept - applications in Sweden, Proceedings of Logistics Research Network, Plymouth: International Logistics and Supply Chain Management.

Roso, V., Woxenius, J., Lumsden, K. (2009) The dry port concept: connecting container seaports with the hinterland, Journal of Transport Geography, 27, 5, 338-345.

Slack, B. (1999) Satellite terminals: a local solution to hub congestion?, Journal of Transport Geography, 7, 241-246.

Slack, B., Comtois, C. (2010) Identification des modèles de gouvernance d'un pôle logistique en lien avec la réalité québécoise, Aménagement d'un pôle logistique au Québec: cadre d'analyse de l'étude de faisabilité, Étude 1.2.

Van Der Horst, M.R., De Langen, P.W. (2008) Coordination in hinterland transport chains: a major challenge for the seaport community, Maritime Economics and Logistics, 10, 108-129.

Veenstra, A., Zuidwijk, R., van Asperen, E. (2012) The extended gate concept for container terminals: expanding the notion of dry ports, Maritime Economics and Logistics, $14(1), 14-32$

Walter, C.K., Poist, R.F. (2004) North American inland port development: international vs domestic shipper preferences, International Journal of Physical Distribution \& Logistics Management, 34(7), 579-597.

Wiegmans, B., E. Masurel and P. Nijkamp (1999) Intermodal freight terminals: an analysis of the terminal market, Transportation Planning and Technology, 23, 105-128 